\title{
Оттолкнуть корабль от причала
}

В.А. КРЮКОВ, член-корреспондент РАН, Институт экономики и организации промышленного производства СО РАН, Новосибирск. E-mail: kryukov@ieie.nsc.ru

Статья-раздумья о сделанном в науке выдающимся советским и российским ученым академиком А. Г. Гранбергом. Задолго до современного «бума» «новой экономической географии" им был разработан инструментарий анализа и количественной оценки межрегиональных взаимодействий. Научные исследования А. Г. Гранберг стремился сочетать с практическим применением разработанных подходов. Особое внимание в 1990-2000-е гг. им уделялось изучению развития арктических территорий страны. В 2000 г. была организована крупносмаштабная экспедиция на судне «Михаил Сомов» по трассе Севморпути, результаты и материалы которой подготовили научную основу многих современных документов и решений по развитию данного региона.

Ключевые слова: А.Г. Гранберг, межрегиональные взаимодействия, исследование Арктики

След, который каждый оставляет в жизни, запечатлен в его делах. Из эпизодов, которые запечатлевает наша память, формируется представление о человеке, о том, что он сделал и к чему стремился. Сделать это тем сложнее, чем более активной и разносторонней была его деятельность. Особенно по прошествии времени - ведь оценки меняются, на многое из того, чему был свидетелем, смотришь уже по-другому.

Наверное, в этом и заключался «секрет успеха» Александра Григорьевича Гранберга - сделать то, что можешь, так, чтобы не было чувства неловкости и ощущения плохо сделанной работы. Его всегда отличали целеустремленность, организованность, самоотдача. Эти черты личности проявлялись во всем: от науки и занятий спортом до руководства большими научными коллективами и реализации крупных проектов. Мне кажется, в полной мере они раскрылись как в создании, развитии и продвижении нового научного направления, так и в стремлении Александра Григорьевича, особенно в 1990-2000-е гг., усилить практическую направленность той работы, которой он посвятил многие годы, и сформировать научные основы такой экономической политики развития России, которая учитывала бы особенности ее пространства и адекватно отражала бы его роль. 
Сферой научных исследований А.Г. Гранберга было изучение влияния фактора пространства (с учетом различий отдельных территорий) на экономическое развитие, которое не сводится к региональной экономике в ее классическом понимании (как науки о факторах и условиях функционирования в рамках определенной замкнутой территории). К сожалению, в последние годы в связи с тем, что в органах исполнительной власти произошла кардинальная смена кадрового состава - место практиков и людей, знающих конкретные вещи, заняли «менеджеры», ориентированные на технологии управления в их самом общем виде, всплеск внимания к пространственной экономике, наблюдавшийся в 1980-е и в 1990-е гг. (не без влияния Александра Григорьевича - в тот период он был советником Президента РФ по региональной политике, а затем было даже создано профильное министерство), сменился забвением.

В настоящее время значительная часть профессионального сообщества в своих выступлениях и исследованиях оперирует растиражированными положениями «новой экономической географии» (кластеры, агломерации, «неизбежность сжатия пространства» ${ }^{1}$ и т. д.).

Подход А.Г. Гранберга был принципиально иным: «преодоление» пространства за счет развития инфраструктуры и усовершенствования тех направлений деятельности, которые обеспечивают в каждом конкретном месте наибольшую социально-экономическую отдачу. При таком взгляде на пространственное развитие есть место и агломерациям, но не только они определяют экономическую динамику в исторических условиях, сложившихся в России.

Фактически Александр Григорьевич получил результат, близкий к тому, который только совсем недавно в явном виде представлен в работе Р. Коуза и Н. Вана [2]: «Повторные и дублирующие инвестиции неизбежны и являются важной частью процесса. Они привели к ослаблению эффекта масштаба из-за недоиспользования капитала, но значительно ускорили и распространили индустриализацию по всей стране... Потери во “внутренней экономии", говоря словами Альфреда Маршалла, были с лихвой компенсированы “внешней экономией".

\footnotetext{
${ }^{1}$ См., например [1].

4 ЭКО. - 2016. - №10
} 
В этом кроется секрет необычайно высоких темпов рыночных преобразований в Китае в 1990-х годах и далее».

Развитие пространства в противовес его неизбежному «сжатию» и усилению центробежных тенденций и централизации могли (и все еще могут) сформировать модель экономического развития, которая в большей степени отвечает специфике и особенностям России. Вместе с тем разработка и практическая реализация такой модели предполагают экономическую активность на местах, невозможную без прав и полномочий в решении долгосрочных экономических и социальных задач. Увы, пока понимание роли и места управления пространством не стало отличительной особенностью модели функционирования экономики и социальной сферы России.

Не случайно важнейшей составляющей деятельности Александра Григорьевича в 1990-2000-е гг. стала работа над крупными региональными проектами - прежде всего, по развитию территории Российский Арктики, в том числе Республики Саха (Якутия) и Полярного Урала. А.Г. Гранберг во многом стоял у истоков современного изучения экономики арктических регионов России.

Многие высказанные им идеи еще ждут своего часа. Среди причин их невостребованности - инерция и боязнь реализации новых подходов, основанных на расширении роли территорий в реализации долгосрочной социально-экономической стратегии. Это сказалось, например, в приостановке проекта «Урал Промышленный - Урал Полярный», в весьма медленном и противоречивом развитии Северного морского пути и в целом Российской Арктики ${ }^{2}$ (например, за коротким всплеском активности судоходства в начале 2010-х гг. последовал значительный спад). Причины связаны и со сложностью данных проектов, и со ставшей традиционной склонностью к использованию простых и проверенных временем решений (увы, созданных для других экономических условий), а также с нехваткой кадров, которые могли бы эффективно и по-современному действовать в нынешней ситуации.

Имеет значение и та новая экономическая реальность, с которой столкнулась Россия - прежде всего, в части решения проблем

${ }^{2}$ См., например [3]. 
развития пространства в условиях быстро и противоречиво реформируемой экономики. Как известно, началу реформ и переходу на иные принципы взаимодействий между хозяйствующими субъектами сопутствовало понимание необходимости повышения роли регионов (реальные экономические процессы происходят, как известно, «на местах»). Но через 5-7 лет «движения по пути реформ» экономическая деятельность была монополизирована под эгидой крупных трансрегиональных структур. Поэтому многие новации управления экономикой страны, связанные с усилением роли регионов, очень скоро отошли на дальний план или даже выпали из «повестки дня». Более того, на экономику пространства стали оказывать искажающее влияние внутриэкономические процедуры на уровне крупных корпораций, которые очень сильно деформировали представления о реальной роли пространственных факторов в развитии России.

В частности, еще в 1997 г. мы обсуждали с А.Г. Гранбергом влияние разных систем учета на уровне крупных вертикально интегрированных корпораций на состояние бюджетной сферы сырьевых регионов (тогда в схемах «оптимизации» налоговых выплат активно применялась такая категория, как «скважинная жидкость», в чем особенно преуспела нефтяная компания «ЮКОС»).

Отличительной особенностью Института экономики и организации промышленного производства (ИЭОПП) Сибирского отделения Академии наук в 1970-1980-х годах была активная экспедиционная деятельность. Всеми нами владело стремление приблизить свои научные изыскания к реальной хозяйственной практике, знать и понимать, что и почему происходит на местах (не только в Арктике или Якутии, но и в сибирских селах и городах, на предприятиях).

Одна из таких широкомасштабных экспедиций (в которой довелось участвовать автору этих строк вместе с Александром Григорьевичем) проводилась в июне-июле 1982 г. на территории Западно-Сибирского нефтегазового комплекса (от Томска до Тюмени и Ямбурга). Следующая подобная по масштабу и продолжительности экспедиция по трассе Северного морского пути - от Архангельска до порта Тикси - состоялась только в июле-августе 2000 г. (автор прошел путь от Архангельска до Салехарда). 
Между этими «эпохальными» экспедициями было совместное участие в уникальном исследовательском суперпроекте в течение 1993-1999 гг. по проблемам освоения трассы Северного морского пути - ИНСРОП (INSROP - International Northern Sea Route Programme) $)^{3}$.

Данный проект (вспомните «лихие 90-е»!) был основан, в первую очередь, на оптимизме и вере в то, что освоение пространства России, развитие транспортной инфраструктуры на севере страны дадут сильный импульс развитию и этих территорий, и экономики всей страны, а также окажут значительное влияние на интеграцию ее в систему мирохозяйственных связей. В проекте участвовали исследователи из многих стран - Японии, Норвегии и США (прежде всего, из Университета штата Аляска). Основную финансовую нагрузку несли научные фонды Аляски, Хоккайдо и Норвегии.

У Александра Григорьевича установились очень теплые и дружеские отношения с профессором Университета штата Аляска Виком Фишером (Vick Fisher), одним из отцов-основателей штата и участников группы по написанию его конституции (он провел детские годы в Москве, так как его отец, Л. Фишер, до войны работал американским корреспондентом в Берлине и Москве; он даже ходил в ту же школу, что и впоследствии Александр Григорьевич [4]). Очень близкие отношения были и с директором Института Фритьофа Нансена Вилли Остренгом (Willy Ostreng, ныне президент Норвежской научной академии полярных исследований [5]).

От России в данном проекте основную нагрузку по согласованию и отстаиванию позиции страны и ее научного сообщества взял на себя А.Г. Гранберг. В этом ему активно помогали сотрудники ЦНИИМФа - Центрального института морского флота в Санкт-Петербурге, а директор института профессор В.И. Пересыпкин был хорошо знаком Александру Григорьевичу еще по экспедиции Института экономики и организации

\footnotetext{
${ }^{3}$ Программа ИНСРОПпродолжалась в течение шести лет - с марта 1993 г. по март 1999 г. Одним из ведущих организаторов проекта был академик А.Г. Гранберг. По ее результатам был собран, обобщен и подготовлен уникальный массив научных данных по различным аспектам развития Арктики (167 рабочих отчетов). Значительная часть материалов находится в открытом доступе (URL: http://www.fni.no/insrop/).
} 
промышленного производства СО РАН по трассе Севморпути на рубеже 1970-1980-х гг. В рамках проекта летом 1995 г. был совершен уникальный трансарктический рейс сухогруза ледового класса «Кандалакша» по маршруту Иокогама (Япония) Киркенес (Норвегия) по арктической трассе, без захода в наши порты и вообще без особых контактов с российским побережьем. Основная цель (судно было зафрахтовано Японским фондом изучения океана и судоходства) состояла в проверке особенностей мореплавания в высоких арктических широтах. Поэтому судно было «обвешано» различной аппаратурой и в российские воды не заходило из-за опасений быть задержанным и обследованным «с пристрастием» (о чем нам позднее поведал капитан во время экспедиции 2000 г.).

Данный рейс, например, подтвердил, что зарубежный грузоотправитель, используя СМП в летнюю навигацию, может ускорить доставку груза на 15 суток по сравнению с южным путем через Суэцкий канал.

А.Г. Гранберг времен экспедиций по Западной Сибири (1982 г.) и по Севморпути (2000 г.) - это одновременно и очень похожие, и очень разные люди. В начале 1980-х годов это больше академический ученый, которого друзья-коллеги прозвали в шутку «трюмным исследователем» по той причине, что он много времени проводил в каюте, в трюмной части корабля, дописывая учебник по моделированию экономики. К 1986 г. ИЭОПП получил статус головной организации РАН по выполнению темы «Комплексный прогноз использования природных ресурсов развития производительных сил зоны Севера СССР на 1991-2015 гг.» под научным руководством академика А. Г. Гранберга (он к тому времени стал директором института).

В экспедиции 2000 г. Александр Григорьевич, набравший колоссальный опыт работы в Верховном Совете РСФСР и в качестве советника Президента РФ по региональной политике, - «деятельный наблюдатель», в поле зрения которого - все вопросы, от формирования графика встреч на местах до очень заинтересованного участия в обсуждениях с коллегами по экспедиции всего увиденного и услышанного.

Снарядить и отправить экспедицию на Север (да еще по трассе Севморпути) никогда не было легким делом: выход судна на трассу требует более 50 подписей - от медицинских до эколо- 
гических и прочих надзорных органов. Александру Григорьевичу удалось сначала получить в распоряжение экспедиции судно «Михаил Сомов», а затем и реально осуществить ее. Последнее оказалось весьма непростым: пока суд да дело, кто-то «реализовал на сторону» машинное масло, необходимое для уникальных дизель-генераторных установок судна. Установки финские, масло к ним поставляла Финляндия, и из-за его отсутствия отправка судна была задержана (до Архангельска срочно отправили бензовоз, благо, что это всего около 1000 км, и график его движения отслеживали сотрудники областной администрации).

Почти десять дней ожиданий и переживаний увенчались успехом - в один из августовских дней 2000 г. к «Михаилу Сомову» подошел маленький (особенно если смотришь с палубы океанского судна) портовый буксир-трудяга и принялся, пыхтя и испуская клубы выхлопного дыма, выводить корабль на чистую воду, подальше от причала.

А перед этим «Михаил Сомов» был торжественно отправлен в рейс с главного рейда Архангельска в День Военно-Морского Флота. Но из-за вышеупомянутых трудностей корабль отправили «с глаз долой» - в бухту Экономия в 20 км ниже по течению Северной Двины. Вынужденное ничегонеделание Александр Григорьевич, со свойственной ему целеустремленностью, сумел обратить во благо задачам экспедиции. Были объявлены семинары (после короткого обсуждения программы), что способствовало сплочению участников и выработке близких взглядов на непростые проблемы освоения Севера и пространственную экономику в целом у представителей разных организаций и научных школ.

Экспедиция и ее результаты опередили время: только через десять с лишним лет Россия вновь обратила взор на Арктику - начали разрабатываться совместные (экономическое развитие территорий Арктики и инфраструктуры Северного морского пути) стратегии и программы, приниматься необходимые документы.

Нельзя не отметить, что Александр Григорьевич собрал в составе экспедиции уникальных людей и специалистов М. К. Бандмана, А. А. Арбатова, Л.Г. Цоя, А. Н. Евдокимова, В.Я. Плаксия и многих других исследователей, посвятивших не один год изучению Севера и Арктики [6]. Александр Григорьевич своим трудом и настойчивостью в достижении поставленной цели «оттолкнул от причала» не только судно «Михаил Сомов», 
рейс которого продвинул нас далеко вперед в понимании проблем Северного морского пути, но и чрезвычайно важное и очень востребованное практикой научное направление - исследование пространственных факторов экономического развития России. Сейчас вполне очевидно, что вне этого направления у нашей страны нет и не может быть не только собственной модели экономического развития, но и своего места в системе мирохозяйственных связей и отношений.

С уходом Александра Григорьевича Гранберга отечественная экономическая наука страны лишилась лидера и активного «движителя» этого важнейшего направления современной науки и практики.

\section{Литература}

1. Доклад о мировом развитии 2009. Новый взгляд на экономическую географию. Обзор. - Всемирный банк: Вашингтон, 2010. - 33 с.

2. Коуз Р., Ван Н. Как Китай стал капиталистическим / Пер. с англ. М.: Новое издательство, 2016. - С. 264 (Библиотека свободы).

3. План мероприятий по реализации Стратегии развития Арктической зоны Российской Федерации и обеспечения национальной безопасности на период до 2020 года, утвержденный Правительством PФ 30.08.2016 г. URL://http://government.ru/media/files/ObB3ODIP9rO AwfYbgWrOzHIxaHTla8s1.pdf

4. Fischer V. To Russia With Love. An Alaskan's Journey. - Wohlforth, Charles. 2012. - 400 p. URL: http://www.alaska.edu/uapress/browse/ detail/index. $x \mathrm{ml}$ ?id $=462$

5. URL: http://www.polar-academy.com/pages/documents/CV_WillyOstreng_07.02.2013.pdf

6. Проблемы Северного морского пути/ Совет по изучению производительных сил РАН. (Отв. ред. - А. Г. Гранберг); Центр. научн. - исслед. и проектно-конструкторский институт морского флота (ЦНИИМФ). М.: Наука, 2006. - 581 с. 